\title{
Seed Invigoration with Paclobutrazol Improves Seedling Growth, Physiological, Biochemical Attributes and Fruit Yield in Okra
}

\author{
Rohina Bashir ${ }^{1}$, Iqbal Hussain ${ }^{1 *}$, Rashid Rasheed ${ }^{1}$, Sumera Anwar $^{2}$, Muhammad Awais $^{3}$ and Samina Hassan $^{4}$ \\ ${ }^{1}$ Department of Botany, Government College University, Faisalabad-38000, Pakistan \\ ${ }^{2}$ Institute of Molecular Biology and Biotechnology, University of Lahore, Pakistan \\ ${ }^{3}$ College of Earth \& Environmental Sciences, University of the Punjab, Lahore, Pakistan \\ ${ }^{4}$ Kinnaird College for Women University, Lahore, Pakistan \\ *For correspondence: driqbal@gcuf.edu.pk \\ Received 06 March 2021; Accepted 29 May 2021; Published 10 July 2021
}

\begin{abstract}
The production of okra is affected by improper seedling growth and abiotic factors like temperature and soil. This study was aimed to examine the effect of paclobutrazol (PBZ) seed priming on the growth, seedling vigor and yield of okra. A pot experiment was conducted in completely randomized design under natural conditions and seeds of two okra varieties were soaked in $0,4,8,10$ and $20 \mathrm{mg} \mathrm{L}^{-1}$ of PBZ solution. Results showed that PBZ seed soaking affected the germination rate and maximum reduction in germination rate was observed at $20 \mathrm{mg} \mathrm{L}^{-1}$ of PBZ. A gradual decrease in plant height was recorded in PBZ treated plants as compared to control. A decrease in plant height of PBZ treated plants was accompanied with an increase in plant biomass and number of branches. PBZ seed soaking resulted in darker green leaves with higher chlorophyll, protein and total free amino acid contents than control plants. The activity of antioxidant enzymes, peroxidase and superoxide dismutase was also higher in PBZ treated plants. The improvement in all vegetative and physiological parameters ultimately had a positive effect on yield. PBZ treated plants showed an increase in the number of pods and pod length while seed weight remained unaffected. Thus, seed priming with optimum doses of PBZ could improve the seedlings and yield of okra. (C) 2021 Friends Science Publishers
\end{abstract}

Keywords: Paclobutrazol; Seed priming; Okra; Fruit yield; Antioxidants

\section{Introduction}

Seed quality and vigor are crucial elements for the stand establishment and productive success of crops (Dotto and Silva 2017). Some techniques like priming, foliar application and soil/medium application of plant growth regulators are being employed to improve seedling vigor and crop productivity. Seed priming is considered to be the most useful strategy being cost-effective and convenient tool (Maiti and Pramanik 2013; Baskin and Baskin 2014; Paparella et al. 2015). Seed soaking in a specific solution triggers normal metabolic processes of germination before radical emergence (Chunthaburee et al. 2014; Ibrahim 2016), and can enhance the germination percentage, decrease germination time and ensures seedlings establishment (Heydariyan et al. 2014; Abiri et al. 2016). Reduction in imbibition time (Brocklehurst and Dearman 2008), and metabolic repair during imbibition, and improved metabolites and enzyme activities related to germination results in increased and synchronized germination of primed seeds.

Seed priming can be categorized into hydropriming, halopriming, osmopriming, and hormone priming (Ibrahim 2016). Hormone priming has been widely used to enhance the germination rate. Previous studies indicated that seed priming with hormones like abscisic acid (Ali et al. 2012; Wei et al. 2017), salicylic acid (Farahmandfar et al. 2013; Ulfat et al. 2017) and gibberellic acid (Chunthaburee et al. 2014) proved effective for increasing seed germination, growth and yield of wheat (Afzal et al. 2005; Iqbal and Ashraf 2013; Ulfat et al. 2017), rice (Khaliq et al. 2015; Wei et al. 2017) beet (Dotto and Silva 2017) and sunflower (Jafri et al. 2015). In addition to these hormones, many reports on seed soaking with Paclobutrazol (PBZ) are also available. Application of PBZ in rooting medium also reduced the adverse effects of abiotic stresses (Anwar et al. 2017). However, the application of PBZ is not effective due to poor penetration into leaf surfaces (Still and Pill 2003).

Paclobutrazol [(2RS, 3RS)-1-(4-chlorophenyl)-4, 4dimethyl-2-(1H-1, 2, 4-trizol-1-yl)-pentan-3-ol] belongs to the triazole family of plant growth regulators. PBZ mediated growth-regulating properties in plants by changing the levels of plant growth regulators like gibberellins, cytokinins and abscisic acid (Jaleel et al. 2008). In broad

To cite this paper: Bashir R, I Hussain, R Rasheed, S Anwar, M Awais, S Hassan (2021). Seed invigoration with paclobutrazol improves seedling growth, physiological, biochemical attributes and fruit yield in okra. Intl J Agric Biol 26:277-286 
way, it influences the isoprenoid pathway, and alters the phytohormone levels by increasing CKs and ABA contents, whilst reducing the ethylene gibberellin synthesis (Kamountsis and Sereli 1999). Its application induces many physiological changes like enhanced production of photosynthetic pigments (Fletcher et al. 2000) and mineral absorption, abiotic stress tolerance, carbohydrate synthesis, flowering and seeds production (Davis et al. 1988; Gopi and Jaleel 2009). It also helps maintain chloroplast structure under water stress conditions by increasing antioxidant enzyme activities and maintaining the membrane stability (Mohamed et al. 2011; Soumya 2014).

The application of PBZ through seed soaking is considered as an alternative, safe and valuable method to improve germination, reduce plant height and no residual impact on fruits (Magnitskiy et al. 2006). Seed priming in 50 or 500 ppm (Still and Pill 2006). PBZ in both tomato and cucumber (Pasian and Bennett 2001; Cho et al. 2002) was effective in reducing plant height and increasing yield. Studies have also shown that seed priming with PBZ (4 ppm) improved seed germination, seedling quality, yield and winter hardiness of rapeseed (Anwar et al. 2017). It enhanced soluble proteins, proline and lignin contents and reduce the transpiration rate by stomatal closure in many crops (Özmen et al. 2003; Jaleel et al. 2006; Wang et al. 2015; Kamran et al. 2018). PBZ has also been found to affect plant growth and development by modifying photosynthetic parameters, which are associated with broader canopy and enhanced light interception (Tesfahun and Menzir 2018). It also delayed leaf senescence and improved flowering and seed yields in different plant species (Davis et al. 1988).

Okra [Abelmoschus esculentus (L.) Moench] is a popular summer vegetable of many tropical countries including Pakistan. However, many factors like adverse environment, poor nutrition, soil physical properties like soil compaction and mechanical hindrance resulted in poor germination and seedling establishment finally affecting the growth and yield of okra (Kusvuran 2012). Most commonly used okra varieties are tall and have short fruiting period. Hard seed coat is another hindrance for okra seed germination (Felipe et al. 2010). In agriculture, rapid and even growth is necessary for maximum yield; the reason why priming is an important solution.

Different growth regulators such as cytokinins, $\mathrm{GA}_{3}$ and auxins have been applied to many vegetables like tomato (Khan et al. 2006), potato (Panwar et al. 2006), spinach (Akhtar et al. 2008) and citrus (Nawaz et al. 2008). But only a few reports are available deciphering the role of PBZ in seedling growth and yield of okra and other vegetables. Keeping in view these facts, the current study was planned to investigate the influence of seed priming with PBZ on germination percentage, seedling growth, physiological condition of the plant and ultimately on yield. This paper is the first report on the use of PBZ as a potential approach to significantly decrease okra plant height with an increase in the number of branches, which results an increase in plant yield under semi-arid climatic conditions.

\section{Materials and Methods}

\section{Experiment site, plant material and growth conditions}

The experiment was conducted in the wire house of Government College University, Faisalabad, Pakistan, during summer season (April-June, 2018), under natural climatic conditions. Average relative humidity was $44.53 \%$, average temperatures during day and night were 38.9 and $24.13^{\circ} \mathrm{C}$, respectively during experiment (PMD 2015). The seeds of two okra varieties namely, Punjab-selection (PS) and Green-gold (GG) were obtained from Ayub Agricultural Research Institute (AARI) Faisalabad, Pakistan. Seeds of both varieties were primed with $50 \mathrm{~mL}$ each of $0,4,8,10$ and $20 \mathrm{mg} \mathrm{L}^{-1} \mathrm{PBZ}$ concentrations for $12 \mathrm{~h}$. After priming, seeds were blotted dried and 10 seed were sown in each plastic pot having $20 \mathrm{~cm}$ diameter. Pots were filled with mixture of soil, sand and debris (2:1:1). The design of experimental was completely randomized with four replicates per treatment. Fresh leaf samples of okra were harvested after 30 days of sowing kept in a freezer at $-20^{\circ} \mathrm{C}$ for determination of different growth and biochemical attributes.

\section{Data collection}

Growth and yield attributes: Pots were examined daily to count number of seeds germinated every day. Germination percentage was calculated by following formula:

$$
\text { Germination } \%=\frac{\text { Number of seeds germinated }}{\text { total number of seeds }} \times 100
$$

Seedlings were harvested after 30 days of germination and fresh weights of shoot and root were examined. Dry mass was calculated after drying in an oven at $80^{\circ} \mathrm{C}$. Seedling length was measured after separating plant roots from shoots. Number of branches was also calculated. Yield parameters were measured at maturity. Number of pods per plant, pod length, number of seeds per pod and 100 seed weight was calculated.

Analysis of chlorophyll contents: For the estimation of chlorophyll contents, $0.5 \mathrm{~g}$ fresh leaf samples were grinded in $80 \%$ acetone and chlorophyll $a, b$ and total chlorophyll was determined using Arnon method (1949). Absorbance of the extract was taken at 480, 645, $663 \mathrm{~nm}$ was measured using spectrophotometer.

Total soluble proteins and total free amino acids: For total soluble protein in fresh leaves of okra was estimated by Bradford method using Coomassie brilliant blue dye (Bradford 1976). The fresh leaf $(0.25 \mathrm{~g})$ was grinded in 10 $\mathrm{mL}$ chilled potassium phosphate buffer $(50 \mathrm{mM})$. The grinded material was centrifuged for $15 \mathrm{~min}$ at 10,000 rpm. Then reaction mixture $(100 \mu \mathrm{L})$ mixed with Bradford reagent $(5 \mathrm{~mL})$ in test tubes. These test tubes were incubated 
in dark for $20 \mathrm{~min}$ and then absorbance at $595 \mathrm{~nm}$ was measured. Hamilton and Van Slyke (1943) method was used for estimation of amino acids. The fresh leaves were grinded in $0.2 \mathrm{M}$ phosphate buffer with $\mathrm{pH}$ (7.0). Then, $1 \%$ pyridine, $2 \%$ ninhydrinwas added in a test tube having $1 \mathrm{~mL}$ plant extract. Test tubes were placed in boiling water bath for $30 \mathrm{~min}$. Reading was taken at $570 \mathrm{~nm}$ on a spectrophotometer. Leucine was used for standard curve and following formula was used for calculation of total free amino acids using the formula:

Leucine equivalent TFAA $=\frac{\text { Reading of sample xvolume of sample } \times \text { dilution factor }}{\text { Fresh leaf weight } \times 1000}$

Antioxidant enzymes assays: For the antioxidant enzyme, fresh leaf $(0.1 \mathrm{~g})$ of okra was homogenized with pestle and mortar in $10 \mathrm{~mL}$ of ice-cold potassium phosphate $(50 \mathrm{mM}$; $\mathrm{pH}$ 7.5). The homogenate was transferred to a plastic centrifuge tube and centrifuged at $10,000 \mathrm{~g}$ for $15 \mathrm{~min}$ at $4^{\circ} \mathrm{C}$ and supernatant obtained. For the estimation of superoxide dismutase (SOD) activity, Giannopolitis and Ries (1977) method was used. The principle of this method is to inhibit photochemical reduction of nitrobluetetrazolium (NBT) at $560 \mathrm{~nm}$. The reaction mixture contains extracted enzyme $(50 \mu \mathrm{L})$ and NBT $(50 \mu \mathrm{L})$, riboflavin $(1.3 \mu \mathrm{L})$, methionine $(13 \mathrm{mM})$ and EDTA $(75 \mathrm{mM})$ in glass test tube (Giannopolitis and Ries 1977). Then the reaction mixture was subjected to 15 watts fluorescent lamps at $79 \mu \mathrm{mol} \mathrm{m}$ $\mathrm{s}^{-1}$ for $15 \mathrm{~min}$. Peroxidase (POD) activities were measured by using Chance and Maehly (1955) method. The reaction volume $(3 \mathrm{~mL})$ contains $100 \mu \mathrm{L}$ enzyme extract, $50 \mathrm{mM}$ phosphate buffer ( $\mathrm{pH} 7.5$ ), $20 \mathrm{mM}$ guaiacol, and $5.9 \mathrm{mM}$ $\mathrm{H}_{2} \mathrm{O}_{2}$. The POD activity was assessed at $470 \mathrm{~nm}$ after every 20 seconds for 2 min using spectrophotometer.

\section{Statistical analysis}

Pots were placed in completely randomized design with three replicates. The collected data were analyzed by twoway analysis of variance (ANOVA) and correlations using Statistix 8.1. software. Means were compared using least significant difference test LSD at $P<0.05$.

\section{Results}

\section{Germination rate and morphological traits}

Priming with PBZ significantly $(\mathrm{p}<0.001)$ decreased seed germination rate in both okra varieties (Fig. 1a). Germination rate decreased with increasing PBZ concentration. PBZ20 (20 $\left.\mathrm{mg} \mathrm{L}^{-1}\right)$ caused $76 \%$ decline in germination rate, while PBZ4 showed a $10 \%$ decrease in PS as compared to control. GG showed $87 \%$ decrease in germination rate at PBZ20 and $8 \%$ decrease at PBZ4. Decrease in germination rate was more in GG as compared to PS. PBZ priming significantly reduced $(\mathrm{p}<0.001)$ plant height and root length of both the okra varieties (Fig. 1). Maximum plant height and root length were recorded in the control (PBZ0), while minimum plant height was observed at PBZ20 but root length was minimum at PBZ10. Maximum decrease in shoot length was $75 \%$ in PS, while $65 \%$ in GG at PBZ20. Root length reduction was $45 \%$ in PS and $47 \%$ in GG at PBZ10. Reduction in shoot length was more in PS than GG. Biomass of okra plants were increased at 4 and $8 \mathrm{mg} \mathrm{L}^{-1} \mathrm{PBZ}$ concentrations, while reduced at higher PBZ (10 and $20 \mathrm{mg} \mathrm{L}^{-1}$ ) concentrations (Fig. 1). Shoot dry biomass was increased by $32 \%$ at PBZ8 in PS. The maximum increase (32\%) in shoot dry biomass was observed at PBZ8, which was $32 \%$ in PS and $19 \%$ in GG. Root dry biomass was also increased at lower PBZ levels. GG showed the highest increase (89\%), while PS exhibited $80 \%$ increase. Maximum numbers of branches were observed at PBZ8 followed by PBZ4 and PBZ10 (Fig. 1). However, at higher concentration $\left(20 \mathrm{mg} \mathrm{L}^{-1}\right)$ maximum reduction in the number of branches was observed. PS showed an increase in the number of branches by $51 \%$, while GG showed increase by $31 \%$ at PBZ8.

\section{Chlorophyll contents}

PBZ priming did not significantly affect chlorophyll $a$ content of both cultivars (Fig. 2). Maximum chlorophyll $a$ content was observed at PBZ8. A maximum increase (15\%) was in total chlorophyll contents were noted in GG and $9 \%$ in PS as compared to control. PBZ priming showed a significant effect $(\mathrm{p}<0.05)$ on chlorophyll $b$ and total chlorophyll content in both okra varieties (Fig. 2). The maximum increase in chlorophyll $b(10 \%)$ and total chlorophyll content (18\%) in GG was observed at PBZ10, while lowest value was observed at PBZ20 in both parameters. GG accumulated higher photosynthetic pigments as compared to control.

\section{Protein, total free amino acids and antioxidants}

PBZ priming also showed a significant effect $(\mathrm{p}<0.01)$ on total free amino acids in both cultivars (Fig. 3a). The highest increase in this attribute $(33 \%)$ was observed in GG at PBZ8. PBZ priming resulted significant increase $(p<0.001)$ in protein contents in both okra varieties (Fig. 3b). Protein content was increased with an increase in PBZ concentration. A higher protein content in PS (27\%) and GG $(33 \%)$ was observed at PBZ20 as compared to control. PBZ priming showed a significant effect $(\mathrm{p}<0.001)$ on POD and SOD dismutase activity (Fig. 3c-d). The maximum increase in POD activity was observed at PBZ20 followed by PBZ10, PBZ8 and PBZ4. PBZ20 showed an increase in POD contents by $27 \%$ in PS, while the $33 \%$ increase in this activity in GG compared to control. Similarly, SOD activity was also significantly $(p<0.001)$ enhanced by the PBZ application, while the variety $\times$ treatment was nonsignificant $(P>0.05)$. The highest increase in SOD $(28 \%)$ was observed at PBZ8 in GG. Increase in antioxidant activity was more in GG as compared to PS. 
Table 1: The effect of seed priming with PBZ on the yield attributes of okra

\begin{tabular}{|c|c|c|c|c|c|c|}
\hline Varieties & Treatments & Number of pods plant $^{-1}$ & Pod length $(\mathrm{cm})$ & Number of seeds pod ${ }^{-1}$ & 100 Seed weight $(\mathrm{g})$ & Grain yield/plant $(\mathrm{g})$ \\
\hline \multirow[t]{4}{*}{ PS } & PBZ0 & $7.40 \pm 0.58^{b}$ & $10.56 \pm 0.79^{\mathrm{b}}$ & $40.01 \pm 1.15^{\mathrm{a}}$ & $8.5 \pm 0.29^{\mathrm{a}}$ & $34.33 \pm 2.03$ \\
\hline & PBZ4 & $9.50 \pm 1.73^{\mathrm{ab}}$ & $12.44 \pm 1.60^{a b}$ & $38.11 \pm 1.15^{\mathrm{ab}}$ & $6.5 \pm 0.94^{\mathrm{abc}}$ & $38.33 \pm 1.85$ \\
\hline & PBZ8 & $12.5 \pm 1.30^{\mathrm{a}}$ & $14.3 \pm 0.72^{\mathrm{a}}$ & $35.03 \pm 1.73^{\mathrm{bcd}}$ & $6.17 \pm 0.44^{\text {bcd }}$ & $50.5 \pm 1.25$ \\
\hline & PBZ20 & $2.61 \pm 0.45^{\mathrm{c}}$ & $5.76 \pm 0.91^{\mathrm{c}}$ & $27.38 \pm 1.44^{\mathrm{e}}$ & $4.33 \pm 0.36^{\mathrm{de}}$ & $27.33 \pm 1.30$ \\
\hline \multirow[t]{4}{*}{ GG } & PBZ0 & $7.07 \pm 0.52^{b}$ & $10.67 \pm 0.92^{b}$ & $38.13 \pm 1.45^{\mathrm{ab}}$ & $7.14 \pm 0.64^{\mathrm{ab}}$ & $33.5 \pm 2.18$ \\
\hline & PBZ4 & $8.0 \pm 1.15^{\mathrm{b}}$ & $12 \pm 1.15^{\mathrm{ab}}$ & $36.33 \pm 1.16^{\mathrm{abc}}$ & $6.25 \pm 0.43^{\mathrm{abc}}$ & $36.15 \pm 1.85$ \\
\hline & PBZ10 & $7.37 \pm 0.68$ & $10 \pm 1.15^{\mathrm{b}}$ & $26.17 \pm 3.32^{\mathrm{ef}}$ & $5.33 \pm 0.88^{\text {bcde }}$ & $24.33 \pm 1.76$ \\
\hline & PBZ20 & $2.27 \pm 0.67^{\mathrm{c}}$ & $4.37 \pm 1.01^{\mathrm{c}}$ & $2167 \pm 2.33^{f}$ & $3.5 \pm 0.57^{\mathrm{e}}$ & $22.00 \pm 1.52$ \\
\hline \multirow[t]{3}{*}{ ANOVA } & Varieties $\left(F_{V}\right)$ & $1.26^{\mathrm{ns}}$ & $1.37^{\mathrm{ns}}$ & $10.92^{* *}$ & $1.67^{\mathrm{ns}}$ & $22.94 * * *$ \\
\hline & $\operatorname{PBZ}\left(F_{P}\right)$ & $106.24^{* * *}$ & $18.18^{* * *}$ & $29.12^{* * *}$ & $9.43^{* * * *}$ & $40.47 * * *$ \\
\hline & $F v \times F p$ & $16.35^{* * *}$ & $0.17^{\mathrm{ns}}$ & $0.57^{\mathrm{ns}}$ & $0.43^{\mathrm{ns}}$ & $2.50^{\mathrm{ns}}$ \\
\hline
\end{tabular}

Values (mean \pm standard errors) followed by same letters within a column indicate non-significant difference at $P=0.05$ based on least significant difference (LSD) test. $F_{v}, F_{p}$, $F_{v} \times F_{p}$ mean $F$-values of varieties, $\mathrm{PBZ}$ and their interactions in variance of analysis. ${ }^{*},{ }^{* *}$ and ${ }^{* * *}$ indicate significant difference at the $P<0.05,0.01$ and 0.001 , respectively
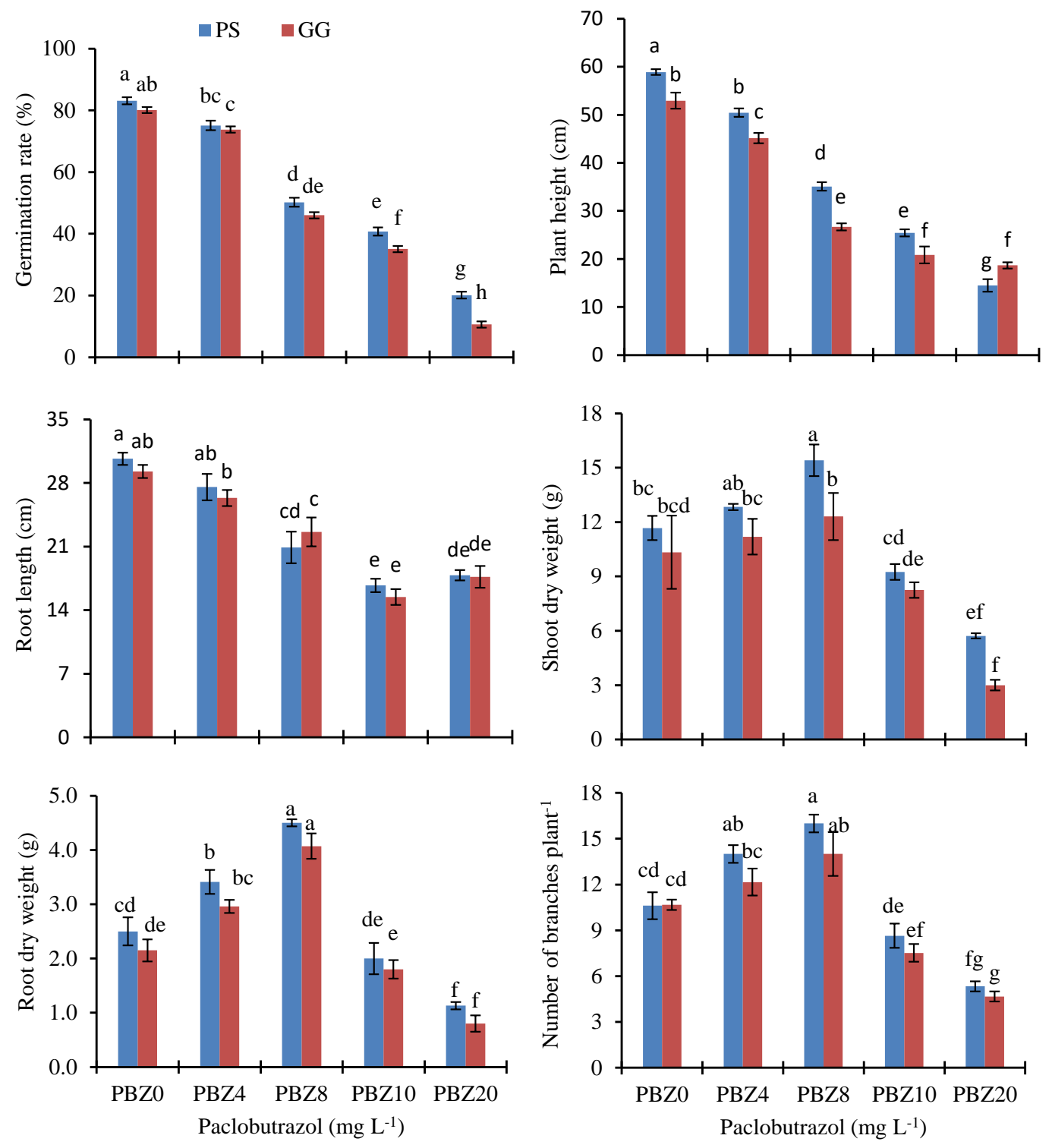

Fig. 1: Changes in growth characteristics in two okra varieties by exogenous application of PBZ $(\mathrm{n}=3 \pm \mathrm{SE})$. Based on LSD test, means shown by same letters are not significantly different at $P=0.05$ 

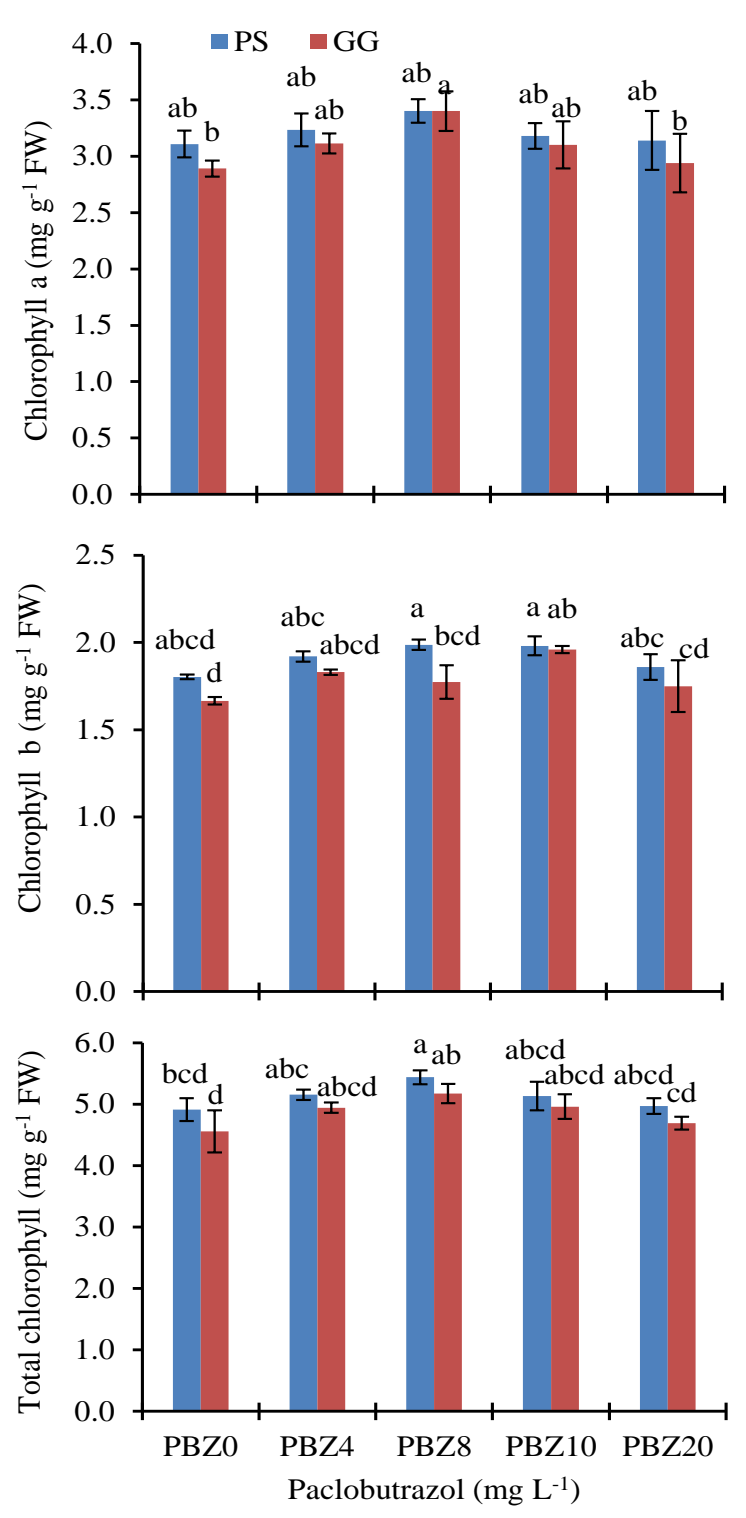

Fig. 2: Changes in chlorophyll contents in two okra varieties by exogenous application of PBZ $(n=3 \pm$ SE). Based on least significant difference (LSD) test, means shown by same letters are not significantly different at $P=0.05$

\section{Yield components}

Seed soaking with PBZ significantly affected the number of pods, number of seeds, pod length and 100-seed weight of okra (Table 1). Number of pods and pod length were increased at lower concentrations of PBZ with maximum at PBZ8 and then decreased by further increasing the concentration of PBZ. Number of pods showed a maximum increase of $69 \%$ in PS and $63 \%$ in GG at PBZ8 as compared to control. The maximum increase in pod length was $35 \%$ at PBZ8 in PS and $22 \%$ in GG. PBZ priming did not increase the number of seeds per pod and 100 seed weight. Number of seeds and 100 seed weight were gradually reduced in
PBZ seed priming. Maximum reduction was observed at PBZ20 in GG. The 100 seeds weight was minimum at PBZ20, which was reduced to $49 \%$ in PS and $51 \%$ in GG as compared to control.

\section{Correlation of yield attributes with growth and physiological parameters}

The correlation matrix analysis was performed to study the correlation between studied parameters. Among yield attributes, yield per plant showed positive correlation with other yield attributes and growth parameters, while negative correlation was observed with some parameters like proteins and POD. 100 seed weight depicted positive correlation with all parameters except Chl. $b$, total free amino acids, proteins and antioxidants. Number of seeds per pod exhibited negative correlation with Chl. $b$, protein and POD. Pod length and number of pods per plant also showed positive correlation with all parameters except protein and POD (Fig. 4).

\section{Discussion}

It is known that PBZ acts as plant growth regulator and at appropriate level makes a remarkable effect on crop growth, physiology and productivity by modifying photosynthetic rate and phytohormone levels (Kim et al. 2012). PBZ application has been known to reduce plant height, growth, internodal length and leaf area. Reduction in plant height is associated with inhibition of gibberellin synthesis, which reduced internodal length (Fletcher et al. 2000). The potential role of PBZ on growth, physiology and yield of tomato with $1 \mathrm{mg} \mathrm{L}^{-1}$ treatment of PBZ as soil application and with $25 \mathrm{mg} \mathrm{L}^{-1}$ foliar application has already been reported (Berova and Zlatev 2000). PBZ application at 1.25 $\mathrm{g} \mathrm{m}^{-1}$ of canopy diameter on Jatropha showed positive effect on vegetative growth and yield (Ghosh et al. 2010). In this study, we investigated the positive response after seed priming with PBZ on okra growth, physiology and yield attributes. Results indicated positive correlation between PBZ use and yield enhancement in okra.

Priming with plant growth retardants offer some common problems like reduction or delay in seed germination and emergence. Similarly, seed germination rate of okra imparted a noticeable sensitivity to $\mathrm{PBZ}$ priming in the present investigation. The germination rate was decreased with an increase in PBZ concentration. Highest PBZ concentration $\left(20 \mathrm{mg} \mathrm{L}^{-1}\right)$ significantly reduced the germination rate in both okra varieties, while lower concentration $\left(4 \mathrm{mg} \mathrm{L}^{-1}\right)$ has a little effect on germination as compared to control (Fig. 1). Seed priming with 1000 ppm PBZ decreased the germination percentage in Cosmos bipinnatus, marigold, tomato and geranium seeds with 500 or 1000 ppm PBZ (Pasian and Bennett 2001; Pill and Gunter 2001). Decline in seed germination may be related to the nature of the seed coat as seeds do not absorb 

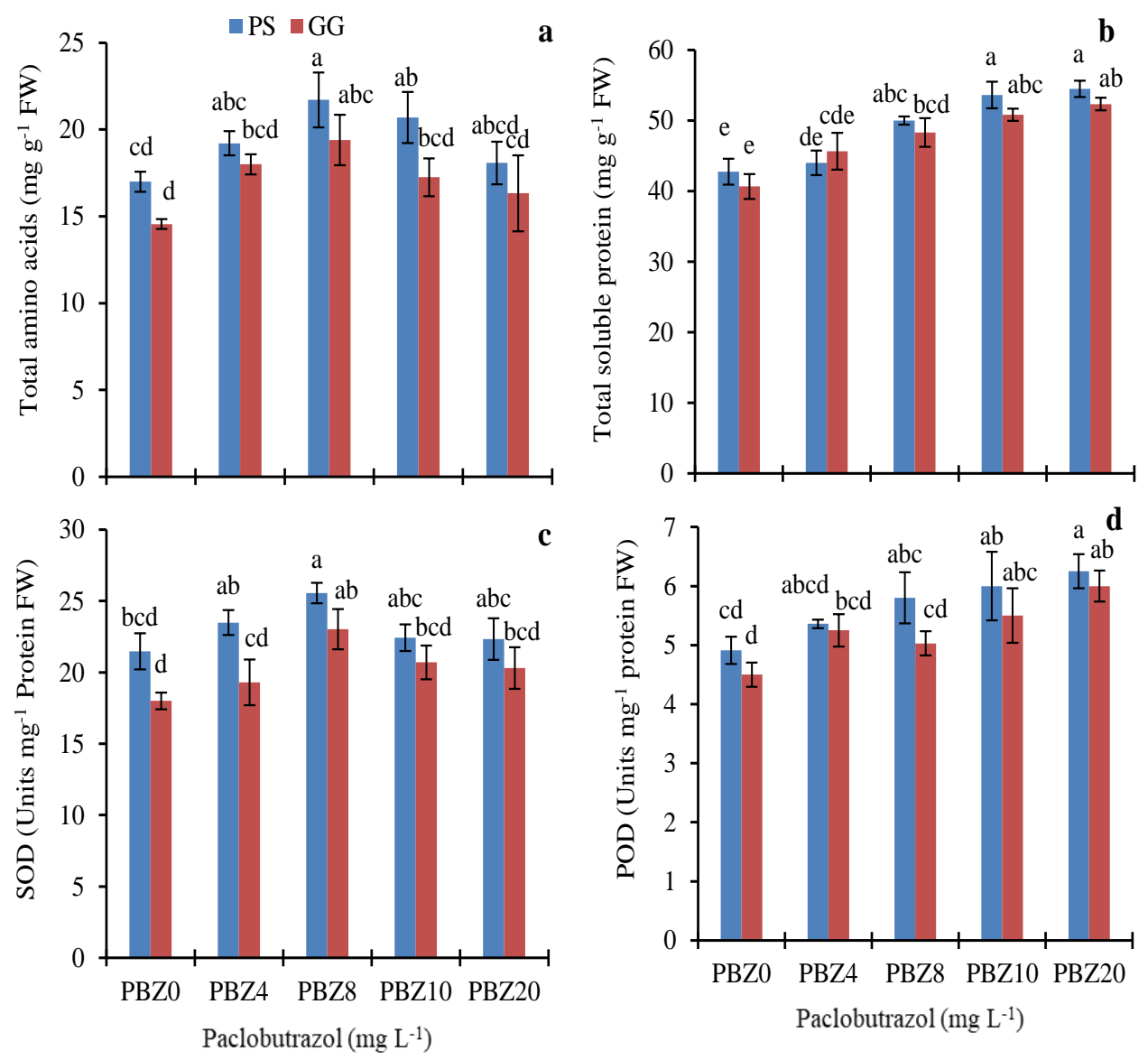

Fig. 3: Changes in (a) total amino acids content, (b) total soluble protein content, (c) superoxide dismutase (SOD) content and (d) peroxidase (POD) content in two okra varieties by exogenous application of PBZ ( $n=3 \pm S E$ ). Based on least significant difference (LSD) test, means shown by same letters are not significantly different at $P=0.05$

PBZ; it only adheres to the seed coat. In general, the reduction in seed germination and emergence might depend on some factors like chemical nature, location and kind of seed coat properties. After sowing, it subsequently diffuses into the rooting media from where it is absorbed by roots (Pasian and Bennet 2001). PBZ repressed radical emergence by hindering gibberellin biosynthesis and its addition to soil medium reversed this process. Such results were demonstrated in proteome analysis of Arabidopsis (Gallardo et al. 2002).

In this study, plant height and root length of both okra varieties were reduced at all the concentrations, but maximum reduction was observed at $20 \mathrm{mg} \mathrm{L}^{-1}$ PBZ (Fig. 1). These findings were in accordance with previously reported investigations by Kumar et al. (2012) in camellias (47.5\% reduction), Syahputra et al. (2013) in rice plants, Koutroubas and DamLas (2015) in sunflower. Decrease in plant height was associated with the inhibition of gibberellin synthesis (Deneke and Keever 1992; Setia et al. 1995; Berova and Zlatev 2000) and decrease in internodal length (Tesfahun and Menzir 2018). Reduction in plant height also altered the branching pattern with respect to an increase in the number of branches. These results corroborate with Kumar et al. (2012) in Camelina, Ghosh et al. (2010) in Jatropha, Bañón et al. (2002) in Dianthus caryophyllus, Yeshitela et al. (2004) in mango. The inhibition of gibberellin biosynthesis disturbed hormonal balance, which activates axillary bud initiation and branches (Woodward and Marshall 1988). It may be related to an increase in dry biomass and yield after PBZ application. In the present study, an increase in plant biomass was observed by PBZ application at $8 \mathrm{mg} \mathrm{L}^{-1}$ but an increase in PBZ concentration declined plant biomass. Yan et al. (2013) reported an increase in root activity and growth in soybean by uniconazole application.

In the present study, after PBZ priming, the leaves were dark green in color and photosynthetic pigments were higher than the control. Maximum chlorophyll contents were observed at $8 \mathrm{mg} \mathrm{L}^{-1} \mathrm{PBZ}$ while in other treatments there was not much difference. An increase in the photosynthetic pigments has been positively associated with an increase in plant growth. Similar findings were reported by Kumar et al. (2012) in Camelina, Dalziel and Lawrence (1984) in sugar beet, Berova and Zlatev (2000) in tomato, 


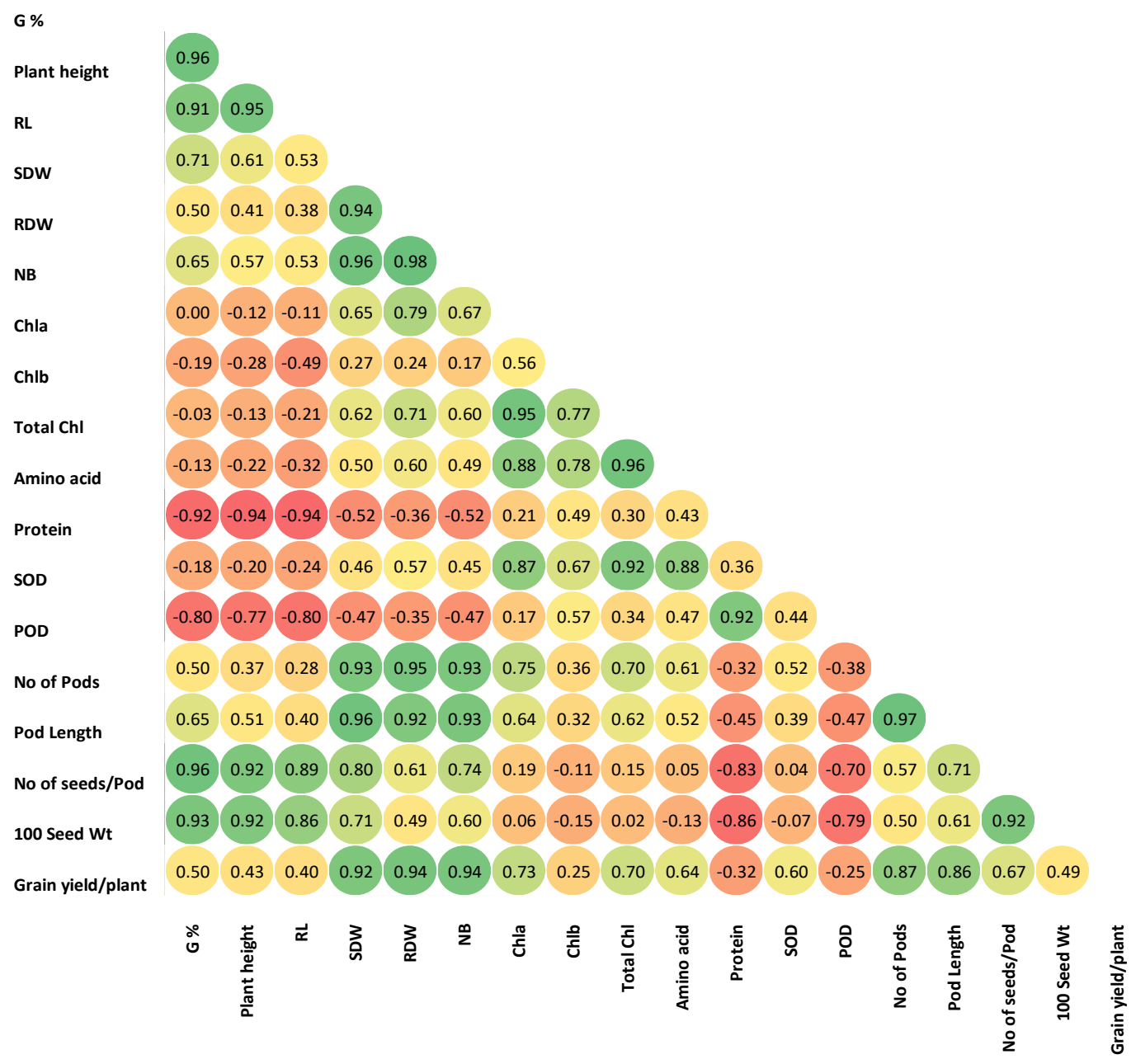

Fig. 4: Correlation among morphological, physiological, antioxidant and yield attributes of okra by PBZ seed priming. G\%: germination percentage; RL: root length; SDW: shoot dry weight; RDW: root dry weight; NB: number of branches; SOD: superoxide dismutase; POD: peroxidase

Belakbir (1998) in pepper; and Sebastian et al. (2002) in Dianthus caryophyllus. Previous reports revealed that increased chlorophyll synthesis by PBZ application was due to an enhanced phytyl production, which is an essential part of chlorophyll molecule. Phytyl is synthesized by the same terpenoid pathway as do the gibberellins. As PBZ inhibits gibberellins biosynthesis, so the terpenoid pathway increased phytyl production by utilizing intermediates of gibberellins synthesis, which ultimately increased chlorophyll contents (Chaney 2003).

Okra seed priming with PBZ enhanced total protein contents in both cultivars as compared to control, but the difference between PBZ levels was not significant. PBZ application increased the cytokinins level, which in turn increased the protein content by stimulating its synthesis and preventing its degradation (Campbell et al. 2008). Priming of okra seeds with PBZ enhanced antioxidant enzyme activities in comparison with control. The increase in POD activity was observed at all PBZ concentrations, while SOD activity was maximum at $8 \mathrm{mg} \mathrm{L}^{-1}$ of $\mathrm{PBZ}$ in both varieties. Previously a positive role of PBZ in ameliorating the adverse effects of water stress by increasing the activity of antioxidants has been reported in many plants including tomatoes, mangoes, groundnuts and sesame seeds (Manivannan et al. 2008; Dahuja and Sharma 2010; Srivastav et al. 2010; Agamy and Rady 2011). An increase in photosynthetic pigments showed an improved photosynthesis and yield (Kumar et al. 2012; Jungklang et al. 2017).

PBZ priming increased the number of pods per plant and maximum number of pods was observed at $8 \mathrm{mg} \mathrm{L}^{-1}$. PBZ also exhibited an increase in the number of flowers, which showed its positive effect on flowering. There are reports that point to changes in phloem to xylem ratio of stem, phenolic contents of terminal buds and total nonstructural carbohydrates in mango (Voon et al. 1991; Kurian and Iyer 1992). An increase in translocation of photoassimilates and nutrients to branches has been reported 
in peanut (Setia et al. 1995) and Brassica napus (AddoQuaye et al. 1985). In our study, PBZ concentration increased number of pods/plant and pod length while number of seeds and seed weight decreased when compared with control.

PBZ priming at $8 \mathrm{mg} \mathrm{L}^{-1}$ followed by $4 \mathrm{mg} \mathrm{L}^{-1} \mathrm{PBZ}$ increased grain yield per plant maximally, but declined as compared to control. This increase may be correlated with an increase in morphological, physiological, and biochemical attributes after PBZ priming at these concentrations. Our studies demonstrated positive correlation of grain yield with germination percentage, plant height, root length, shoot and root dry weight, chlorophyll contents, amino acids and antioxidants (Fig. 4).

The PBZ priming of okra seeds had positive effects on seedling vigor and yield. Seedling vigor is associated with an increase in fresh and dry biomass, number of branches, photosynthetic pigments, antioxidant enzyme activities, protein contents, number of pods/plant and seed yield per plant. Likewise, seed yield per plant exhibited a positive correlation with different growth attributes and chlorophyll pigment in the present study, while negative correlation between yield attribute (100 seed weight) and biochemical attributes (total free amino acids, total soluble protein content, SOD and POD contents) were observed (Fig. 4). Therefore, incubation of okra seeds with PBZ improved seedling vigor by reducing plant height and improving morphological and physiological parameters.

\section{Conclusion}

This is the first report on the use of PBZ as priming agent to minimize height and increase yield in okra. PBZ proved very effective in controlling plant height at lower concentration $\left(8 \mathrm{mg} \mathrm{L}^{-1}\right)$. It also improved all physiological parameters including chlorophyll, protein and total free amino acid contents together with antioxidant enzymes activities. The increase in physiological parameters has a positive influence on okra yield. Seed soaking with PBZ can be used as a potential strategy to improve growth and yield of crops.

\section{Acknowledgements}

The data presented in this manuscript is MS thesis work of Rashid Rasheed. Authors are thankful to Department of Botany, Government College University, Faisalabad for providing research facilities to accomplish this research work.

\section{Author Contributions}

$\mathrm{RB}$ and IH supervised the whole research work; RR performed the research work; RB, IH, MA and SA interpreted results and wrote first draft. All authors read and approved the final script.

\section{Conflicts of Interest}

No conflict of interest is declared by authors

\section{Data Availability}

Data is available with the author and will be made available on a reasonable request.

\section{Ethics Approval}

Not applicable

\section{References}

Abiri R, NA Shaharuddin, M Maziah, ZNB Yusof, N Atabaki, M Sahebi, P Azizi (2016). Quantitative assessment of indica rice germination to hydropriming, hormonal priming and polyethylene glycol priming. Chil J Agric Res 76:392-400

Addo-Quaye AA, RW Daniels, DH Scarisbrick (1985). The influence of paclobutrazol on the distribution and utilization of 14C-labelled assimilate fixed at anthesis in oilseed rape (Brassica napus L.). $J$ Agric Sci 105:365-373

Afzal I, SMA Basra, N Ahmad, M Farooq (2005). Optimization of hormonal priming techniques for alleviation of salinity stress in wheat (Triticum aestivum L.). Caderno de Pesq Sér Biol 17:95-109

Akhtar N, M Ibrar, N Aman (2008). The effects of different soaking times and concentrations of GA3 on seed germination and growth of Spinacia oleracea L. Pak J Plant Sci 14:9-13

Ali HM, MH Siddiqui, MO Basalah, MH Al-Whaibi, HM Sakran, A AlAmri (2012). Effects of gibberellic acid on growth and photosynthetic pigments of Hibiscus sabdariffa L. under salt stress. Afr J Biotechnol 11:800-804

Anwar S, H Lei, J Kuai, S Khan, S Fahad, G Zhou (2017). Soaking seeds of winter rapeseed with Quizalofop-P-Ethyl alters plant growth and improves yield in a rice-rapeseed cropping system. Field Crops Res 208:11-17

Arnon DI (1949). Copper enzymes in isolated chloroplast. Polyphenoloxidase in Beta vulgaris. Plant Physiol 24:1-15

Bañón S, A González, EA Cano, JA Franco, JA Fernández (2002). Growth, development and colour response of potted Dianthus caryophyllus cv. Mondriaan to paclobutrazol treatment. Sci Hortic 94:371-377

Baskin CC, JM Baskin (2014). Seeds: Ecology, Biogeography, and Evolution of Dormancy and Germination, $2^{\text {nd }}$ edn. Academic Press, San Diego, USA

Belakbir A (1998). Yield and fruit quality of pepper (Capsicum аппиит L.) in response to bioregulators. Hortic Sci 33:85-87

Berova M, Z Zlatev (2000). Physiological response and yield of paclobutrazol treated tomato plants (Lycopersicon esculentus Mill.). Plant Growth Regul 30:117-123

Bradford MM (1976). A rapid and sensitive method for the quantitation of microgram quantities of protein utilizing the principle of protein-dye binding. Ann Biochem 72:248-254

Brocklehurst PA, J Dearman (2008). Interaction between seed priming treatments and nine seed lots of carrot, celery and onion II. Seedling emergence and plant growth. Ann Appl Biol 102:585-593

Campbell NA, JB Reece, LA Urry, ML Cain, SA Wasserman, PV Minorsky, RB Jackson (2008). Biology, $8^{\text {th }}$ edn. Benjamin Cummings, San Francisco, California, USA

Chance B, AC Maehly (1955). Assay of catalase and peroxidase. Meth Enzymol 2:764-775

Chaney WR (2003). Tree growth retardants:Arborists discovering new uses for an old tool. Tree Care Indus Mag 54:2-6

Cho KC, WM Yang, WS Kim, SJ Chung (2002). Growth retardation of cucumber (Cucumus sativus L.) seedlings by treatment of paclobutrazol and removal of retardation by foliar spray of gibberellin. J Kor Soc Hortic Sci 43:415-420 
Chunthaburee S, J Sanitchon, W Pattanagul, P Theerakulpisut (2014). Alleviation of salt stress in seedlings of black glutinous rice by seed priming with spermidine and gibberellic acid. Not Bot Hortic Agrobot 42:405-413

Dalziel J, DK Lawrence (1984). Biochemical and biological effects of kaurene oxidase inhibitors, such as paclobutrazol. Brit Plant Growth Regul Group Monogr 11:43-57

Davis TD, GL Steffens, N Sankhla (1988). Triazol plant growth regulators. Hortic Rev 10:151-188

Deneke CF, GJ Keever (1992). Comparison of application methods of paclobutrazol for height control of potted tulips. Hortic Sci 27:13-29

Dotto L, VN Silva (2017). Beet seed priming with growth regulators. Semina: Ciencias Agrarias 38:1785-1798

Farahmandfar E, MB Shirvan, SA Sooran, D Hoseinzadeh (2013). Effect of seed priming on morphological and physiological parameters of fenugreek seedlings under salt stress. Intl J Agric Crop Sci 5:811815

Felipe VP, AL Antonio, AP Francisco (2010). Improvement of okra (Abelmoschus esculentus L.) hard seedness by using microelements fertilizer. Hortic Bras 28:232-235

Fletcher R, A Gilley, N Sankhla, T Davis (2000). Triazoles as plant growth regulators and stress protectants. Hortic Rev 24:55-137

Gallardo K, C Job, SP Groot, M Puype, H Demol, JV Andekerckhove (2002). Proteomics of Arabidopsis seed germination. A comparative study of wild-type and gibberellin-deficient seeds. Plant Physiol 129:823-837

Ghosh A, J Chikara, DR Chaudhary, AR Prakash, G Boricha, A Zala (2010). Paclobutrazol arrests vegetative growth and unveils unexpressed yield potential of Jatropha curca. J Plant Growth Regul 29:307-315

Giannopolitis CN, SK Ries (1977). Superoxide dismutases occurrence in higher plants. Plant Physiol 59:309-314

Gopi R, C Jaleel (2009). Photosynthetic alterations in Amorphophallus campanulatus with triazoles drenching. Glob J Mol Sci 4:15-18

Hamilton PB, DD Van Slyke (1943). The gasometric determination of free amino acids in blood filtrates by the ninhydrin- carbon dioxide method. J Biol Chem 150:231-250

Heydariyan M, N Basirani, M Sharifi-Rad, I Kammari, SR Poor (2014). Effect of seed priming on germination and seedling growth of the caper (Capparis spinosa) under drought stress. Intl J Adv Biol Biom Res 2:2381-2389

Ibrahim EA (2016). Seed priming to alleviate salinity stress in germinating seeds. J Plant Physiol 192:38-46

Iqbal M, M Ashraf (2013). Alleviation of salinity-induced perturbations in ionic and hormonal concentrations in spring wheat through seed preconditioning in synthetic auxins. Acta Physiol Plantarum 35:1093-1112

Jafri N, M Mazid, F Mohammad (2015). Responses of seed priming with gibberellic acid on yield and oil quality of sunflower (Helianthus annus L.). Ind J Agric Res 49:235-240

Jaleel CA, R Gopi, GM AlaguLakshmanan, R Panneerselvam (2006). Triadimefon induced changes in the antioxidant metabolismand ajmalicine production in Catharanthus roseus (L.) G. Don. Plant Sci 171:271-276

Jaleel CA, R Gopi, R Panneerselvam (2008). Biochemical alterations in white yam (Dioscorea rotundata Poir.) under triazole fungicides: impacts on tuber quality. Czech J Food Sci. 26:298-307

Jungklang J, K Saengnil, J Uthaibutra (2017). Effects of water-deficit stress and paclobutrazol on growth, relative water content, electrolyte leakage, proline content and some antioxidant changes in Curcuma alismatifolia Gagnep. Cv. Chiang Mai Pink. Saudi J Biol Sci 24:5051512

Kamountsis AP, C Sereli (1999). Paclobutrazol affects growth and flower bud production in gardenia under different light regimes. Hortic Sci 34:674-675

Kamran M, S Wennan, I Ahmad, M Xiangping, C Wenwen, Z Xudong, M Siwei, A Khan, H Qingfang, L Tiening (2018). Application of paclobutrazol affect maize grain yield by regulating root morphological and physiological characteristics under a semi-arid region. Sci Rep 8; Article 4818
Khaliq A, F Aslam, A Matloob, S Hussain, M Geng, A Wahid, H Rehman (2015). Seed priming with selenium: Consequences for emergence, seedling growth and biochemical attributes of rice. Biol Trace Elem Res 166:236-244

Khan MMA, C Gautam, F Mohammad, MH Siddiqui, M Naeem, MN Khan (2006). Effect of gibberellic acid spray on performance of tomato. Turk J Bot 30:11-16

Kim J, RL Wilson, JB Case, BM Binder (2012). A comparative study of ethylene growth response kinetics in eudicots and monocots reveals a role for gibberellin in growth inhibition and recovery. Plant Physiol 160:1567-1580

Koutroubas SD, CA DamLas (2015). Sunflower response to repeated foliar applications of paclobutrazol. Planta Danin 33:129-135

Kumar S, S Ghatty, J Satyanaryana, A Guha, BSK Chaitanya, AR Reddy (2012). Paclobutrazol treatment as a potential strategy for higher seed and oil yield in field-grown Camelina sativa L. Crantz. BMC Res Notes 5; Article 137

Kurian RM, CPA Iyer (1992). Stem anatomical characteristics in relation to tree vigour in mango (Mangifera indica L.). Sci Hortic 50:245-253

Kusvuran S (2012). Influence of drought stress on growth, ion accumulation and antioxidative enzymes in okra genotypes. Intl J Agric Biol 14:401-406

Magnitskiy SV, CC Pasian, MA Bennett, JD Metzger (2006). Effects of soaking cucumber and tomato seeds in paclobutrazol solutions on fruit weight, fruit size and paclobutrazol level in fruits. Hortic Sci 41:1446-1448

Maiti R, K Pramanik (2013). Vegetable seed priming: low cost, simple and powerful techniques for farmers' livelihood. Intl J Bio-Resour Stress Manage 4:475-481

Manivannan P, C Abdul Jaleel, A Kishorekumar, B Sankar, R Somasundaram, R Panneerselvam (2008). Protection of Vigna unguiculata (L.) Walp. plants form salt stress by paclobutrazol. Colloid Surf 61:315-318

Mohamed GF, RA Agamy, MM Rady (2011). Ameliorative effects of some antioxidants on water-stressed tomato (Lycopersicon esculentum Mill.) plants. J Appl Sci Res 7:2470-2478

Nawaz MA, W Ahmad, S Ahmad, MM Khan (2008). Role of growth regulators on preharvest fruit drop, yield and quality in kinnow mandarin. Pak J Bot 40:1971-1981

Özmen AD, F Özdemir, I Türkan (2003). Effects of paclobutrazol on response of two barley cultivars to salt stress. Biol Plantarum 46:263-268

Panwar RD, SS Sindhu, JR Sharma, RS Saini (2006). Effect of gibberellic acid spray on growth, flowering, quality and yield of bulbs in tuberose. Haryana J Hortic Sci 35:253-255

Paparella S, SS Araujo, G Rossi, M Wijayasinghe, D Carbonera, A Balestrazzi (2015). Seed priming: state of the art and new perspectives. Plant Cell Rep 34:1281-1293

Pasian C, M Bennett (2001). Paclobutrazol soaked marigold, geranium and tomato seeds produce short seedlings. Hortic Sci 36:721-723

Pill WG, JA Gunter (2001). Emergence and shoot growth of cosmos and marigold from paclobutrazol treated seed. J Environ Hortic 19:11-14

PMD (2015). Climate and astronomical data. http://www.pmd.gov.pk/

Sebastian B, G Alberto, AC Emilio, AF Jose, AF Juan (2002). Growth development and color response of potted Dianthus caryophyllus to paclobutrazol treatment. Sci Hortic 94:371-377

Setia RC, G Bhathal, N Setia (1995). Influence of paclobutrazol on growth and yield of Brassica carinata. Plant Growth Regul 16:121-127

Srivastav M, A Kishor, A Dahuja, RR Sharma (2010). Effect of paclobutrazol and salinity on leakage, proline content and activities of antioxidant enzyme in mango (Mangifera indica L.). Sci Hortic 125:785-788

Soumya PR (2014). Role of paclobutrazol in amelioration of water deficit stress in chickpea (Cicer arietinum L.). M.Sc. Thesis, Indian Agricultural Research Institute, New Delhi, India

Still JR, WG Pill (2003). Germination, emergence, and seedling growth of tomato and impatiens in response to seed treatment with paclobutrazol. Hortic Sci 38:1201-1204

Still JR, WG Pill (2006). Growth and stress tolerance of tomato seedlings (Lycopersicon esculentum Mill.) in response to seed treatment with paclobutrazol. J Hortic Sci Biotechnol 81:197-203 
Syahputra BAS, UR Sinniah, SO Syed Rastan, MR Ismail (2013). Changes in gibberellic acid (GA) content in Oryza sativa due to paclobutrazol treatment. J Food Pharm Sci 1:14-17

Tesfahun W, A Menzir (2018). Effect of rates and time of paclobutrazol application on growth, lodging, yield and yield components of Tef [Eragrostis Tef (Zucc.) Trotter] in Ada district, East Shewa, Ethiopia. J Biol Agric Healthcare 8:104-117

Ulfat A, SA Majid, A Hameed (2017) Hormonal seed priming improves wheat (Triticuma estivum L.) field performance under drought and non-stress conditions. Pak J Bot 49:12391253

Voon CH, C Pitakpaivan SJ Tan (1991). Mango cropping manipulation with Cultar. Acta Hortic 291:219-228

Wang C, D Hu, X Liu, H She, R Ruan, H Yang, Z Yi, D Wu (2015). Effects of uniconazole on the lignin metabolism and lodging resistance of culm in common buckwheat (Fagopyrum esculentum M.). Field Crop Res 180:46-53
Wei LX, BS Lv, X Li, M Wang, M Hongyuan, R Yang, ZZ Piao, Z Wang, JH Lou, CJ Jiang, Z Liang (2017). Priming of rice (Oryza sativa L.) seedlings with abscisic acid enhances seedling survival, plant growth, and grain yield in saline-alkaline paddy fields. Field Crops Res 203:86-93

Woodward EJ, C Marshall (1988). Effect of plant growth regulators and nutrient supply on tiller bud outgrowth in barley (Hordeum distichu L.). Ann Bot 61:347-354

Yan W, Y Yanhong, Y Wenyu, YTaiwen, L Weiguo, W Xiaochun (2013). Responses of root growth and nitrogen transfer metabolism to uniconazole, a growth retardant, during the seedling stage of soybean under relay strip intercropping system. Commun Soil Sci Plant Anal 44:3267-3280

Yeshitela T, PJ Robbertse, PJC Stassen (2004). Paclobutrazol suppressed vegetative growth and improved yield as well as fruit quality of 'Tommy Atkins' mango (Mangifera indica) in Ethiopia. Crop Hortic Sci 32:281-293 